\title{
Jurnal Bisnis dan Manajemen
}

\author{
https://jurnal.unej.ac.id/index.php/BISMA
}

Jurnal Bisma, Vol. 13 No.2, 2019, pp 131 - 138

\section{PENGARUH MODAL MANUSIA DAN STRUKTUR ASET TERHADAP RISIKO KREDIT DAN KINERJA KEUANGAN PADA BANK KONVENSIONAL DI INDONESIA}

\author{
Ahmad Roziq, Septarina Prita Dania Sofianti, Wasito, Agung Budi Sulistiyo \\ Fakultas Ekonomi dan Bisnis, Universitas Jember, Jember
}

\begin{abstract}
Abstrak
Penelitian ini bertujuan untuk menguji pengaruh human capital dan struktur aset terhadap risiko kredit dan kinerja keuangan serta pengaruh risiko kredit terhadap kinerja keuangan pada bank konvensional di Indonesia. Penelitian ini adalah penelitian eksplanatori dengan sampel penelitian terdiri dari 25 bank konvensional di Indonesia selama periode tahun 2013 hingga 2017. Metode analisis data yang digunakan adalah Partial Least Square (PLS). Hasil penelitian menunjukkan bahwa: (a) human capital tidak memiliki pengaruh yang signifikan terhadap risiko kredit bank konvensional di Indonesia, (b) human capital tidak memiliki pengaruh yang signifikan terhadap kinerja keuangan bank konvensional di Indonesia, (c) risiko kredit memiliki pengaruh signifikan terhadap kinerja keuangan bank konvensional di Indonesia, (d) struktur aset memiliki pengaruh signifikan terhadap risiko kredit bank konvensional di Indonesia, dan (e) struktur aset tidak memiliki pengaruh signifikan terhadap kinerja keuangan bank konvensional di Indonesia.
\end{abstract}

Kata Kunci : $\quad$ human capital, kinerja keuangan, risiko kredit, struktur aset

\begin{abstract}
\begin{tabular}{l|l} 
Abstract & This study aims to examine the influence of human capital and asset structure on credit
\end{tabular} risk and financial performance and the influence of credit risk on financial performance of conventional banks in Indonesia. This is an explanatory research with the sample consisted of 25 conventional banks in Indonesia during the period of 2013 to 2017. Data were analyzed using PLS. The results showed that: (a) human capital has no significant influence on credit risk of the conventional banks in Indonesia; (b) human capital has no significant influence on the financial performance of conventional banks in Indonesia, (c) credit risk has significant influence on the financial performance of conventional banks in Indonesia, (d) asset structure has significant influence on the credit risk of conventional banks in Indonesia, and (e) asset structure has no significant influence on the financial performance of conventional banks in Indonesia.
\end{abstract}

Keywords : $\quad$ asset structure, credit risk, financial performance, human capital

\section{Pendahuluan}

Pada periode 2002-2006, perbankan konvensional cukup berhasil dalam menghasilkan pendapatan. Ini tidak terlepas dari berbagai layanan dan produk yang disediakan oleh bank konvensional, seperti $e$ banking, internet-banking, phone-banking, sms-

Fakultas Ekonomi dan Bisnis, Universitas Jember Jalan Kalimantan No. 37 Jember

E-mail: agungbudisulistiyo@gmail.com banking, dan produk lainnya. Sebaliknya, tenaga kerja selalu merupakan input yang paling tidak efisien. Ini tidak terlepas dari sifat industri jasa di mana modal yang paling penting adalah sumber daya manusia yang terampil dan berpengalaman. Selanjutnya, deposito meningkat, tetapi distribusi kredit (pembiayaan) menurun. Salah satu faktor yang berkontribusi adalah tingginya suku 
bunga pada waktu itu yang lebih tinggi dari suku bunga pinjaman, sehingga bank konvensional cenderung berperilaku menempatkan dana mereka pada Sertifikat Bank Indonesia (SBI) daripada menyalurkan pinjaman. Hal ini tercermin dari rasio pinjaman terhadap simpanan (LDR) perbankan konvensional yang relatif rendah dibandingkan dengan kondisi sebelum krisis, dan posisi SBI juga cenderung menunjukkan peningkatan. Dengan demikian bank konvensional tidak perlu menyalurkan kredit untuk menghasilkan laba.

Sejalan dengan masalah ini, penting untuk memeriksa variabel yang memiliki hubungan langsung dan tidak langsung dengan kinerja keuangan bank konvensional. Dengan mengetahui variabel yang memengaruhi kinerja bank konvensional, lebih mudah bagi kami untuk menemukan solusi untuk masalah kinerja keuangan bank konvensional dan secara kritis menilai rendahnya kinerja bank konvensional. Melalui tinjauan literatur dan studi empiris, variabel dapat diperoleh yang memiliki pengaruh langsung atau tidak langsung pada kinerja keuangan bank konvensional seperti dijelaskan di bawah ini.

Menurut Martono (2002) prinsip konvensional yang digunakan oleh bank konvensional menggunakan dua metode, yaitu menetapkan bunga sebagai harga, baik untuk produk tabungan seperti tabungan, deposito berjangka, dan produk pinjaman (kredit) yang diberikan berdasarkan suku bunga tertentu. Untuk layanan bank lain, bank menggunakan atau menerapkan berbagai biaya dalam nominal atau persentase tertentu. Sistem penetapan biaya ini disebut berbasis biaya. Fungsi intermediasi adalah kegiatan operasional utama di sektor perbankan untuk mendukung pencapaian kinerja bank yang diharapkan. Fungsi intermediasi dimulai dari mengumpulkan dana pihak ketiga dan kemudian mendistribusikan dana yang dikumpulkan dalam bentuk pembiayaan. Fungsi intermediasi memiliki efek positif yang signifikan terhadap kinerja bank syariah di Indonesia secara langsung atau tidak langsung melalui risiko pembiayaan.

Sehubungan dengan proporsi pendanaan yang berasal dari kewajiban atau ekuitas perusahaan, penting untuk melihat pengaruh struktur modal terhadap kinerja keuangan perusahaan. Rasio hutang terhadap ekuitas, rasio hutang terhadap modal jangka panjang, total rasio hutang terhadap ekuitas, ukuran perusahaan, dan pertumbuhan penjualan sebagai faktor yang memengaruhi profitabilitas. Hasilnya menunjukkan rasio hutang terhadap modal jangka pendek, total rasio hutang terhadap modal, ukuran perusahaan, pertumbuhan penjualan yang tinggi, menyebabkan profitabilitas yang lebih tinggi. Weston dan Brigham (1994) menyatakan bahwa salah satu keputusan penting manajer keuangan untuk tetap kompetitif dalam jangka panjang adalah keputusan mengenai struktur modal. Struktur modal penting karena memengaruhi posisi keuangan dan risiko perusahaan. Struktur modal dalam lembaga keuangan dan perbankan adalah penentuan biaya agensi sektor keuangan dalam perekonomian (Shoaib, 2011).

Dalam era keterbukaan digital informasi saat ini, modal manusia menjadi bagian esensial dari modal intelektual perusahaan (Mayo, 2012; Flamholtz dan Randle, 2012), dan memiliki dampak yang signifikan pada model dan sistem pengawasan manajemen (Coff, 1997; Lisa et al, 2004). Sejalan dengan riset sebelumnya tersebut, modal manusia juga berpengaruh positif pada kinerja keuangan organisasi terutama pendapatan atau kompensasi.

Berkaitan dengan resiko kredit dalam perbankan maka perlu menjadi perhatian yang vital karena menentukan keberlangsungan organisasi dalam jangka panjang. Selaras dengan enterprise theory yang menekankan pentingnya mengelola resiko dibutuhkan manajemen modal manusia yang mumpuni dan memadai. Dalam beberapa kajian, modal manusia sering disetarakan dengan modal intelektual. Guimond (2012) menunjukkan adanya efek yang positif antara modal inteletual ini dengan penurunan resiko kredit.

Menurut Mai (2006) tipologi resiko kredit juga dipengaruhi oleh struktur aset perusahaan. Semakin baik komposisi aset perusahaan termasuk perbankan akan mengurangi resiko 
kreditnya sehingga meningkatkan kinerja keuangan, dalam hal ini tingkat profitabilitasnya.

Berdasarkan latar belakang yang telah dijelaskan sebelumnya, dapat dirumuskan masalah-masalah berikut: (a) apakah modal manusia memiliki pengaruh yang signifikan terhadap risiko kredit bank konvensional di Indonesia; (b) apakah modal manusia memiliki pengaruh signifikan terhadap kinerja keuangan bank konvensional di Indonesia (c) apakah struktur aset memiliki pengaruh signifikan terhadap risiko kredit bank konvensional di Indonesia; (d) apakah struktur aset memiliki pengaruh yang signifikan terhadap kinerja keuangan bank konvensional di Indonesia dan (e) apakah risiko kredit memiliki pengaruh signifikan terhadap kinerja keuangan bank konvensional di Indonesia.

Sejalan dengan perkembangan peradaban sosial dan meningkatnya akuntabilitas publik oleh perusahaan, konsep teoritis akuntansi juga telah berubah. Salah satu teori yang berkontribusi besar terhadap perubahan dalam disiplin akuntansi adalah enterprise theory. Pada dasarnya, teori ini lebih fokus pada keterlibatan semua pihak atau pemangku kepentingan, baik yang terkait langsung maupun tidak langsung dengan perusahaan. Misalnya pemilik, manajemen, pelanggan, komunitas, pemerintah, kreditor, karyawan, dan pihak berkepentingan lainnya. Dalam teori ini, pihak-pihak ini harus dianggap sebagai bagian dari penyajian informasi laporan keuangan. Menurut teori ini, akuntansi tidak hanya memberikan informasi bagi pemilik perusahaan, tetapi juga pihak lain yang telah berkontribusi secara langsung atau tidak langsung terhadap keberadaan dan keberhasilan suatu perusahaan atau lembaga.

Dengan demikian, konsep ini diterapkan pada perusahaan dalam skala besar dan modern, karena dari perspektif akuntansi menunjukkan bahwa tanggung jawab pelaporan keuangan tidak hanya disampaikan kepada pemegang saham dan kreditor, tetapi juga kepada masyarakat secara keseluruhan. Pendekatan yang ditawarkan oleh Triyuwono (2006) tentang kinerja sesuai dengan definisi kinerja yang dikemukakan oleh Prawiro
(1997: 2), yaitu bahwa pekerjaan yang dicapai oleh seseorang atau sekelompok orang dalam suatu organisasi adalah proporsional dengan wewenang dan tanggung jawab masingmasing dalam mencapai tujuan organisasi. melanggar hukum atau tidak melanggar hukum dan sesuai dengan moral dan etika.

Aliran positif adalah perspektif yang banyak dikenal oleh para akademisi. Aliran ini pertama kali diperkenalkan di Chichago University, kemudian diperluas ke beberapa universitas lain di Amerika Serikat, seperti Rochester, Barkley, Stanford, UCLA dan New York. Tujuan dari teori akuntansi positif adalah untuk menjelaskan (menjelaskan) dan memprediksi (memprediksi) praktik akuntansi. Penjelasan berarti memberikan alasan untuk praktik yang diamati. Sebagai contoh, teori akuntansi positif berusaha menjelaskan mengapa perusahaan terus menggunakan akuntansi biaya historis dan mengapa perusahaan tertentu mengubah teknik akuntansi mereka. Aktivitas memprediksi praktik akuntansi berarti bahwa teori mencoba memprediksi fenomena akuntansi yang belum diamati.

Kehadiran teori akuntansi positif telah memberikan kontribusi signifikan terhadap perkembangan akuntansi. Kontribusi teori akuntansi positif untuk pengembangan akuntansi adalah untuk menghasilkan pola sistematis dalam pilihan akuntansi dan memberikan penjelasan spesifik untuk polapola ini, memberikan kerangka kerja yang jelas untuk memahami akuntansi, menunjukkan peran utama biaya kontrak dalam teori akuntansi, menjelaskan mengapa akuntansi menggunakan dan menyediakan kerangka kerja untuk memprediksi pilihan opsi akuntansi, mendorong penelitian yang relevan di mana akuntansi menekankan prediksi dan penjelasan dari fenomena akuntansi.

Dorongan terbesar teori akuntansi positif dalam akuntansi adalah untuk menjelaskan dan memprediksi pilihan standar manajemen melalui analisis biaya dan manfaat pengungkapan keuangan tertentu dalam kaitannya dengan berbagai individu dan alokasi sumber daya ekonomi. Teori akuntansi positif didasarkan pada argumen bahwa 
manajer, pemegang saham, dan regulator adalah rasional dan bahwa mereka berusaha memaksimalkan penggunaannya yang secara langsung berkaitan dengan kompensasi mereka, dan tentu saja kesejahteraan mereka. Pilihan kebijakan akuntansi oleh beberapa kelompok ini tergantung pada perbandingan relatif biaya dan manfaat dari prosedur akuntansi alternatif sedemikian rupa untuk memaksimalkan kegunaannya.

Bank konvensional dapat diartikan sebagai bank komersial dalam Pasal 1 ayat 3 UU No. 10 tahun 1998 dengan menghilangkan kalimat dan atau berdasarkan prinsip syariah yaitu bank yang melakukan kegiatan usaha konvensional yang dalam kegiatannya memberikan layanan dalam lalu lintas pembayaran. Bank konvensional adalah bank yang dalam operasinya menerapkan metode bunga, karena metode bunga sudah ada terlebih dahulu, menjadi kebiasaan dan telah digunakan secara luas dibandingkan dengan metode bagi hasil.

Kasmir (2012; 12) menyatakan lembaga keuangan yang kegiatan utamanya mengumpulkan dana dari publik dan mendistribusikan kembali dana ini kepada publik dan menyediakan layanan bank lainnya. Bank adalah lembaga keuangan, pencipta uang, pengumpul dana dan penyalur kredit, pelaksana lalu lintas pembayaran, penstabil moneter dan dinamika pertumbuhan ekonomi. Konsep perbankan konvensional didasarkan pada bunga sebagai instrumennya. bahwa itu dikenal sebagai nilai waktu dari uang sebagai paradigma yang menghasilkan metode nilai sekarang dan nilai masa depan.Kemudian perkembangan dalam transaksi uang di bank konvensional, termasuk, dalam bentuk bunga, melahirkan transaksi spekulatif (al-gharar) dan tanpa didasarkan pada kegiatan bisnis nyata, seperti swap.

Peran sektor perbankan tidak diragukan bahwa sangat penting untuk menghidupkan kembali kegiatan ekonomi. Peran ini akan sangat ditentukan oleh strategi pembangunan yang ditetapkan oleh kekuatan politik baru yang berkuasa, di samping kepentingan komersial kekuatan aktor asing yang tidak dapat diabaikan. Jelas, beberapa orang sangat berharap bahwa sektor perbankan akan ditempatkan kembali sebagai agen pembangunan setelah melayani lebih dan lebih sebagai reservoir yang mengairi kegiatan bisnis kelompoknya sendiri. Beberapa masalah ekonomi mendasar yang harus menjadi fokus peran sektor perbankan meliputi: (a) pemenuhan kebutuhan primer (pakaian, makanan, dan tempat tinggal); (b) penciptaan lapangan kerja dan peningkatan pendapatan; (c) pengembangan industri unggul yang menghasilkan produk substitusi impor; (d) pertumbuhan industri yang berorientasi ekspor dengan konten lokal. Sistem perbankan yang sehat dan kuat diperlukan untuk memainkan peran dalam mengurangi masalah utama ekonomi, baik perbankan konvensional maupun perbankan Islam. Beberapa tantangan internal sektor perbankan adalah: (a) meningkatkan kualitas aset melalui restrukturisasi kredit; (B) memperkuat basis modal; (c) memiliki strategi bisnis yang berfokus pada kompetensi inti tertentu sebagai daya saing; (d) memperkuat basis sistem operasional untuk memperluas sistem distribusi distribusi kredit; (e) meningkatkan kualitas sumber daya manusia dan kualitas layanan.

Berdasarkan landasan teori yang telah diuraikan, berikut ini kerangka kerja konseptual dalam penelitian ini untuk menggambarkan pengaruh modal manusia dan struktur aset terhadap risiko kredit dan kinerja keuangan dan pengaruh risiko terhadap kinerja keuangan pada bank konvensional di Indonesia

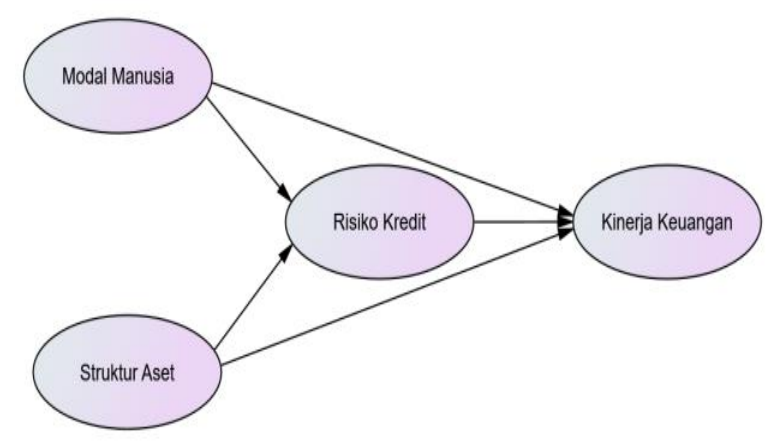

Gambar 1. Kerangka Konseptual Penelitian

Berdasarkan landasan teori dan kerangka kerja konseptual penelitian di atas, hipotesis penelitian adalah sebagai berikut: 
H1: Modal manusia memiliki pengaruh yang signifikan terhadap risiko kredit bank konvensional di Indonesia;

H2: Modal manusia memiliki pengaruh yang signifikan terhadap kinerja keuangan bank konvensional di Indonesia

H3: Struktur aset memiliki pengaruh yang signifikan terhadap risiko kredit bank konvensional di Indonesia

H4: Struktur aset memiliki pengaruh yang signifikan terhadap kinerja keuangan bank konvensional di Indonesia dan

H5: Risiko kredit memiliki pengaruh signifikan terhadap kinerja keuangan bank konvensional di Indonesia.

\section{Metodologi}

Jenis penelitian yang digunakan adalah explanatory research, yaitu penelitian yang bertujuan untuk menganalisis hubungan antara satu variabel dengan variabel lainnya atau bagaimana suatu variabel memengaruhi variabel lainnya. Penelitian ini dimaksudkan untuk menjelaskan hubungan sebab akibat antara variabel penelitian dan menguji hipotesis yang telah dirumuskan. Jenis data yang digunakan dalam penelitian ini adalah data sekunder. Data sekunder adalah sumber data penelitian yang diperoleh peneliti secara tidak langsung melalui media perantara atau diperoleh dan direkam oleh pihak lain. Data tersebut diperoleh dari laporan tahunan dan laporan keuangan bank konvensional antara periode 2013-2017. Laporan-laporan ini diperoleh dari Direktori Perbankan Indonesia di Otoritas Jasa Keuangan dan situs web resmi masing-masing Bank konvensional.

Populasi dalam penelitian ini adalah semua bank konvensional yang telah terdaftar di Direktori Perbankan Indonesia. Sampel penelitian diambil dengan metode purposive sampling, yaitu jenis pemilihan sampel yang tidak acak karena tujuan atau target tertentu (Indriantoro dan Supomo, 2009). Sampel penelitian adalah dalam bentuk semua bank konvensional yang telah terdaftar di Direktori Perbankan Indonesia dan telah menerbitkan laporan tahunan, dan laporan keuangan antara periode 2013-2017. Penelitian ini menggunakan dua jenis variabel penelitian, yaitu variabel eksogen dan variabel endogen. Variabel eksogen adalah variabel yang dianggap memiliki pengaruh terhadap variabel lain, tetapi tidak dipengaruhi oleh variabel lain dalam penelitian ini. Variabel eksogen dalam penelitian ini adalah modal manusia dan struktur aset. Variabel endogen adalah variabel yang dianggap dipengaruhi oleh variabel lain dalam penelitian ini. Variabel endogen dalam penelitian ini adalah risiko kredit dan kinerja keuangan bank konvensional.

Dalam penelitian ini, analisis data menggunakan pendekatan Partial Least Square (PLS) menggunakan perangkat lunak SmartPLS. PLS adalah analisis persamaan struktural berbasis varian (SEM) yang secara bersamaan dapat menguji model pengukuran saat menguji model struktural. PLS adalah pendekatan alternatif yang bergeser dari pendekatan SEM berbasis kovarian menjadi berbasis varian. SEM berbasis kovarian umumnya menguji kausalitas atau teori sementara PLS lebih prediktif. PLS adalah metode analitik yang kuat karena tidak didasarkan pada banyak asumsi. Misalnya, data harus didistribusikan secara normal dan sampel tidak harus besar. Selain digunakan untuk mengkonfirmasi teori, PLS juga dapat digunakan untuk menjelaskan apakah ada hubungan antara variabel laten. PLS dapat secara bersamaan menganalisis konstruksi yang dibentuk oleh indikator reflektif dan formatif. Ini tidak dapat dilakukan oleh SEM berbasis kovarian karena akan menjadi model yang tidak dikenal. Pendekatan PLS adalah distribusi bebas (tidak mengasumsikan data terdistribusi tertentu, dapat berupa nominal, kategori, ordinal, interval atau rasio). PLS tepat untuk model prediktif, teori dasar lemah (membangun teori baru), mengabaikan asumsi klasik sehingga PLS lebih kuat secara praktis karena lebih efisien dalam proses eksekusi.

\section{Hasil dan Pembahasan}

Analisis jalur digunakan untuk menganalisis pola hubungan antar variabel untuk menentukan efek langsung atau tidak langsung dari satu set variabel independen 
(eksogen) pada variabel dependen (endogen). Melalui analisis jalur ini, dapat ditemukan jalur mana yang paling tepat dan pendek dari variabel eksogen menuju variabel endogen yang terikat. Berikut ini adalah model analisis jalur yang ditunjukkan pada gambar 2 pada hasil analisis jalur

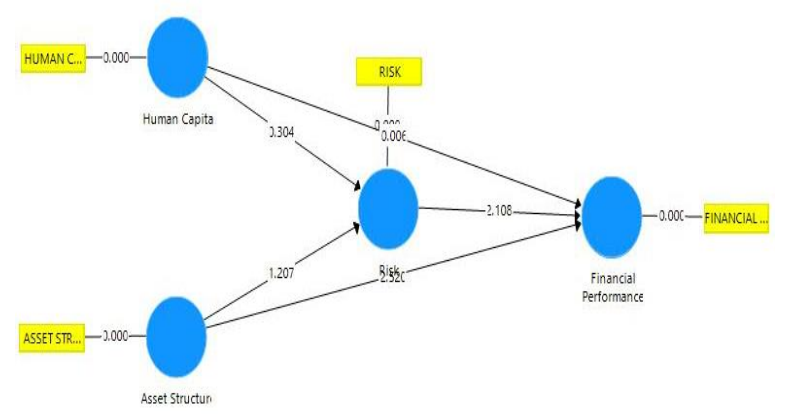

Gambar 2. Analisis Jalur

Sumber : data diolah, 2019

Hasil pengujian pada hipotesis yang diajukan dalam penelitian ini diperoleh berdasarkan pengujian koefisien jalur dari model analisis jalur pada tabel 1. Jika nilai p lebih kecil dari 0,05 maka pengaruh hubungan antar variabel adalah signifikan. Sebaliknya, jika nilai $p$ lebih besar dari 0,05 maka pengaruh hubungan antar variabel tidak signifikan. Hasil tes hipotesis dijelaskan dalam tabel 2 berikut

Berdasarkan tabel 1, hasil pengujian hipotesis dijelaskan sebagai berikut. Hipotesis satu (H1) modal manusia tidak memiliki pengaruh yang signifikan terhadap risiko kredit. Pengujian hipotesis pertama dilihat dari koefisien -0,001 dengan nilai-p 0,995 dan nilai-t 0,007. Hipotesis satu ditolak sehingga modal manusia tidak memiliki pengaruh yang signifikan terhadap risiko kredit. Dalam pandangan tradisional, enterprise theory menilai bahwa modal manusia merupakan faktor penggerak penting kemajuan sebuah organisasi. Namun demikian, dalam era digital bisnis, modal manusia tidak memiliki peran yang signifikan lagi jika tidak ditunjang dengan kapasitas intelektual yang mumpuni dan sensitif terhadap perkembangan teknologi.

Hipotesis dua (H2) modal manusia tidak memiliki pengaruh yang signifikan terhadap kinerja keuangan. Pengujian hipotesis kedua dilihat dari koefisien -0,020 dengan p-value
0,758 dan t-value 0,309. Hipotesis kedua terbukti ditolak sehingga human capital tidak memiliki pengaruh yang signifikan terhadap kinerja keuangan. Sejalan dengan Wardini dan Idrus (2012) modal manusia tidak memengaruhi kinerja keuangan. Hal ini dapat dijustifikasi dengan pendapat Blyler dan Coff (2003) bahwa modal manusia tidak akan berdampak signifikan jika tidak memiliki koneksi sosial yang memadai sehingga menyulitkan dalam meningkatkan profitabilitas organisasi.

Hipotesis tiga (H3) risiko kredit memiliki pengaruh signifikan terhadap kinerja keuangan. Pengujian hipotesis ketiga dilihat dari koefisien -0,247 dengan nilai-p 0,042 dan nilai-t 2,043. Hipotesis ketiga terbukti diterima sehingga risiko kredit memiliki pengaruh yang signifikan terhadap kinerja keuangan. Sejalan dengan temuan Agustina dkk (2017) bahwa resiko kredit berpengaruh negatif terhadap kinerja keuangan. Enterprise theory menekankan pentingnya mengelola resiko organisasi sehingga keberlangsungan perusahaan lebih terjaga sehingga menimbulkan kenyamanan bagi stakeholder yang tentunya berdampak pada kinerja keuangan perbankan.

Hipotesis empat (H4) struktur aset memiliki pengaruh signifikan terhadap risiko kredit. Pengujian hipotesis keempat dilihat dari koefisien -0,157 dengan nilai-p 0,012 dan nilai-t 2,527. Hipotesis keempat terbukti diterima maka struktur aset berpengaruh signifikan terhadap risiko kredit.

Hipotesis lima (H5) struktur aset tidak memiliki pengaruh yang signifikan terhadap kinerja keuangan. Pengujian hipotesis kelima dilihat dari koefisien -0,146 dengan nilai-p 0,197 dan nilai-t 1,293. Hipotesis kelima terbukti ditolak sehingga struktur Asset tidak memiliki pengaruh yang signifikan terhadap kinerja keuangan. Hipotesis lima ditolak.

Koefisien determinasi (R2) pada dasarnya mengukur seberapa jauh kemampuan model untuk menjelaskan variasi variabel dependen. Koefisien determinasi adalah antara nol dan satu. Nilai R2 yang kecil berarti kemampuan variabel independen untuk menjelaskan variasi dalam variabel dependen sangat 
terbatas. Nilai yang mendekati satu berarti bahwa variabel independen menyediakan hampir semua informasi yang diperlukan untuk memprediksi variasi dalam variabel dependen (Ghozali, 2011: 97). Berikut ini adalah hasil analisis koefisien determinasi yang dapat dilihat pada tabel $\mathrm{R}$ square yang disesuaikan.

Tabel 1. Hasil Pengujian Koefisien Determinan

\begin{tabular}{clcc}
\hline Model & R Square & $\begin{array}{c}\text { Adjusted R } \\
\text { Square }\end{array}$ \\
\hline 1 & $\begin{array}{l}\text { Financial } \\
\text { Performance }\end{array}$ & 0.074 & 0.041 \\
\hline 2 & Credit Risk & 0.022 & 0.001 \\
\hline
\end{tabular}

Sumber : data diolah, 2019

Berdasarkan Tabel 1 di atas terdapat koefisien determinasi (adjusted $r$ square) sebesar 0,170 untuk model regresi 1 . Persentase pengaruh variabel modal manusia, struktur aset dan risiko kredit terhadap kinerja keuangan dapat diperoleh dengan mengalikan $\mathrm{R}$ square nilai $100 \%$. Kemudian hasil yang diperoleh dari uji koefisien determinasi adalah 4,1\%. Nilai ini menunjukkan bahwa kemampuan variabel independen dalam hal ini t-tabel dapat menjelaskan variabel dependen dalam hal ini kinerja keuangan sebesar 4,1\% sedangkan sisanya 95,9\% dijelaskan oleh variabel lain yang tidak diteliti atau yang tidak termasuk dalam model regresi.

Dalam model regresi 2, koefisien determinasi adalah 0,267. Persentase pengaruh modal manusia, variabel struktur aset terhadap variabel risiko kredit dapat diperoleh dengan mengalikan nilai $\mathrm{R}$ square dengan $100 \%$. Kemudian hasil yang diperoleh dari uji koefisien determinasi adalah sebesar 0,1\%. Nilai ini menunjukkan bahwa kemampuan variabel independen dalam hal ini human capital, struktur aset dapat menjelaskan variabel dependen dalam hal ini risiko kredit adalah $0,1 \%$ sedangkan sisanya 99,9\% dijelaskan oleh variabel lain yang tidak diperiksa atau yang tidak dimasukkan dalam model regresi.

\section{Kesimpulan}

Secara umum penelitian ini memberikan kesimpulan bahwa pertama, modal manusia tidak memiliki pengaruh yang signifikan terhadap risik kredit bank konvensional di Indonesia. Kedua, Sumber daya manusia tidak memiliki pengaruh yang signifikan terhadap kinerja keuangan bank konvensional di Indonesia. Ketiga, Risiko kredit memiliki pengaruh yang signifikan terhadap kinerja keuangan bank konvensional di Indonesia

Adapun hasil yang keempat menunjukkan bahwa struktur aset memiliki pengaruh yang signifikan terhadap risiko kredit bank konvensional di Indonesia, dan kelima, struktur aset tidak memiliki pengaruh yang signifikan terhadap kinerja keuangan bank konvensional di Indonesia

\section{Saran}

Secara keseluruhan penelitian ini memiliki keterbatasan berupa data sekunder yang tidak sepenuhnya menghasilkan temuan yang signifikan, oleh karena itu pada riset selanjutnya perlu diupayakan untuk menambah data pengamatan dan obyek perusahaan yang diperluas sehingga hasilnya bisa lebih signifikan dan memuaskan.

Agenda penelitian mendatang dapat menggunakan variabel-variabel mikro dari modal manusia dan mengembangkan variabel kinerja non keuangan perbankan sebagai alternatif pengukuran yang lebih holistik dibandingkan kinerja keuangan.

\section{Daftar Referensi}

Agustina, Nurul, Ahmad Roziq, Ade Puspito. 2017. Pengaruh Modal Intelektual, Good Corporate Governance, dan Capital terhadap Kinerja Perusahaan dengan Resiko Kredit Sebagai Variabel Intervening pada Perbankan yang Terdaftar di Bursa Efek Indonesia Tahun 2014-2016, http://repository.unmuhjember.ac.id

Bank Indonesia, Lembaga Perbankan dalam http://www.bi.go.id/web/id/Perbankan/Ikhti sar+Perbankan/Lembaga+Perbankan/, diunggah pada 10 Februari 2011.

Coff, Russell.1997. Human Assets and Management Dilemmas: Coping with Hazards on the Road to Resource-Based Theory, The Academy of Management Review, Vol. 22(2), pp. 374-402

Flamholtz, Eric G., Yvonne Randle.2012. Corporate culture, business models, competitive advantage, strategic assets and the bottom line: Theoretical and measurement issues, 
Journal of Human Resource Costing \& Accounting, Vol. 16 No. 2, 2012 pp. 76-94.

Ghozali, Imam dan Anis Chariri. 2007. Teori Akuntansi, Edisi 3, Semarang: Badan Penerbit Universitas Diponegoro.

Ghozali, Imam. 2011. Aplikasi Analisis Multivariate Dengan Program SPSS, Semarang: Badan Penerbit Universitas Diponegoro.

Guimond, Simonelli. 2012. Development of the Obstetric Nursing Self Efficacy Scale Instrument.Clin Smul Nurs.pp227-232

Indriantoro, Supomo. 2009. Metedologi Penelitian Bisnis Untuk Akuntansi \& Bisnis. Edisi Pertama, BPFE, Yogyakarta.

Jensen, Michael M. 1976. Reflections on The State of Accounting Research and The Regulation of Accounting, Stanford Lectures in accounting: 1976, Graduate School of Business, Stanford University, Palo Alto, California.

Kasmir.2004. Manajemen Perbankan, Jakarta: Raja Grafindo Persada.

Lisa Bryant, Denise A. Jones, and Sally K. Widener .2004.Managing Value Creation within the Firm: An Examination of Multiple Performance Measures. Journal of Management Accounting Research: December 2004, Vol. 16, No. 1, pp. 107-131.

Mai, Muhammad Umar.2006.Analisis VariabelVariabel yang Mempengaruhi Struktur Modal Pada Perusahaan-Perusahaan LQ45 di Bursa Efek Jakarta, Ekonomika, Hal. 228- 245.

Martono.2002. Bank dan Lembaga Keuangan Lain, Yogyakarta: Ekonisia.

Mayo, Andrew. 2012. Human Resources or Human Capital, Gower Pub.

Nurul Huda dan Mustafa Edwin Nasution (Ed).2009. Current Issues Lembaga Keuangan Syariah, Jakarta: Kencana.

Prawiro, D. 1997. Kewirausahaan. Yogyakarta: Andi

Shoaib, Adnan. 2011, Measuring Performance Through Capital Structure: Evidence from Banking Sector of Pakistan (November 29, 2010). African Journal of Business Management, Vol. 5, No. 5, pp. 1871-1879.

Triyuwono, Iwan. 2006. Perspektif, Metodologi, dan Teori Akuntansi Syariah. PT Raja Grafindo: Jakarta.

Weston, J.F dan Brigham.1994. Dasar Managemen Keuangan, Jakarta: Erlangga. 